\title{
Glycomacropeptide Prevents Iron/Ascorbate-Induced Oxidative Stress, Inflammation and Insulin Sensitivity with an Impact on Lipoprotein Production in Intestinal Caco-2/15 Cells
}

\author{
Mathilde Foisy-Sauvé ${ }^{1,2}$, Lena Ahmarani ${ }^{1}$, Edgard Delvin ${ }^{1}(1)$, Alain T. Sané ${ }^{1}$, \\ Schohraya Spahis ${ }^{1,2}$ and Emile Levy $1,2, *$ (D) \\ 1 Research Centre, CHU Ste-Justine, Montreal, QC H3T 1C5, Canada; mfois067@uottawa.ca (M.F.-S.); \\ lena_ahm@yahoo.com (L.A.); delvine@sympatico.ca (E.D.); sanealaintheo@gmail.com (A.T.S.); \\ schohraya.spahis@recherche-ste-justine.qc.ca (S.S.) \\ 2 Department of Nutrition, Université de Montréal, Montreal, QC H3T 1A8, Canada \\ * Correspondence: emile.levy@recherche-ste-justine.qc.ca; Tel.: +(514)-345-7783
}

Received: 26 March 2020; Accepted: 20 April 2020; Published: 22 April 2020

\begin{abstract}
Background. Metabolic Syndrome (MetS), a major worldwide concern for the public health system, refers to a cluster of key metabolic components, and represents a risk factor for diabetes and cardiovascular diseases. As oxidative stress (OxS) and inflammation are the major triggers of insulin sensitivity (IS), a cardinal MetS feature, the principal aim of the present work is to determine whether glycomacropeptide (GMP), a milk-derived bioactive peptide, exerts beneficial effects on their expression. Methods. Fully differentiated intestinal Caco- $2 / 15$ cells are used to evaluate the preventive action of $2 \mathrm{mg} / \mathrm{mL}$ GMP against OxS and inflammation induced by the mixture iron-ascorbate (Fe/Asc) $(200 \mu \mathrm{M}: 2 \mathrm{mM})$. The potency of GMP of decreasing the production of lipoproteins, including chylomicrons (CM), very-low-density lipoproteins (VLDL) and low-density lipoproteins (LDL) is also assessed. Results. The administration of GMP significantly reduces malondialdehyde, a biomarker of lipid peroxidation, and raises superoxide dismutase 2 and glutathione peroxidase via the induction of the nuclear factor erythroid 2-related factor 2, a transcription factor, which orchestrates cellular antioxidant defenses. Similarly, GMP markedly lowers the inflammatory agents tumor necrosis factor- $\alpha$ and cyclooxygenase- 2 via abrogation of the nuclear transcription factor-kB. Moreover, GMP-treated cells show a down-regulation of Fe/Asc-induced mitogen activated protein kinase pathway, suggesting greater IS. Finally, GMP decreases the production of CM, VLDL, and LDL. Conclusions. Our results highlight the effectiveness of GMP in attenuating OxS, inflammation and lipoprotein biogenesis, as well as improving IS, the key components of MetS. Further investigation is needed to elucidate the mechanisms mediating the preventive action of GMP.
\end{abstract}

Keywords: glycomacropeptide; oxidative stress; inflammation; insulin sensitivity; metabolic syndrome; milk-derived bioactive peptide

\section{Introduction}

The intestine plays an essential role in nutrient digestion and absorption. It also actively participates in host protection and metabolism by housing much of the human microbiota [1,2]. It exerts a marked influence on health, being equipped with a strong neuroendocrine system, producing a number of centrally and peripherally metabolically effective peptides [3-5]. In addition, not only does the intestine act as a physical barrier to protect the body from the harsh luminal environment, but 
also through its intraluminal microbiota in order to modulate energy metabolism and inflammation processes associated with obesity and diabetes [6].

The assertion that the gastrointestinal (GI) tract represents a meaningful target to treat conditions conducive to cardiometabolic disorders (CMD) is of clinical relevance. For instance, Schauer et al. [7] have shown in a 5-year prospective randomized controlled trial that bariatric surgery coupled to intensive medical treatment results in a better control of dysglycemia and remission of type 2-diabetes than medical treatment alone. However, when bariatric surgery does not represent an optimal option, uncovering new nutrients with a significantly intestinal metabolic impact is crucial to assure prevention and treatment of CMD. In this context, there is a growing interest in bioactive peptides, such as growth and immunity factors, derived from human and bovine milk given their high potential in assuring health benefits for neonates, infants, adolescents and adults [8-13]. However, most of the beneficial effects described for milk-derived peptides have not been exhaustively investigated in link with the GI system. Furthermore, little is known about their effects on CMD and even less on the related mechanistic aspects.

Bovine kappa-caseino glycomacropeptide or glycomacropeptide (GMP), a 64-amino acid glycophosphopeptide, has been described as one of the most biologically active milk component $[14,15]$. This carbohydrate-containing compound can survive gastric transit without hydrolysis and is absorbed intact into the bloodstream [16,17]. Even if 30 years ago GMP was considered as a source of energy, it now becomes obvious that it has also the potential of modulating various biological processes, including binding of cholera toxin and E. Coli enterotoxins, inhibition of bacterial and viral adhesion, suppression of gastric secretion, and promotion of bifidobacterial growth [18-22]. The anti-inflammatory and immunomodulatory effects of GMP have been reported in rodent models of inflammatory bowel disease [23,24], murine spleen and bone marrow dendritic cells $[25,26]$, as well as in lymphocytes and macrophages [27]. Until very recently, few animal studies have enlightened the capacity of GMP to attenuate metabolic disorders such as diabetes and dyslipidemia without addressing the underlying mechanisms [28-30]. Lately, Yuan et al. [30] demonstrated that supplementing diabetic mice with a GMP hydrolysate significantly reduced fasting blood glucose, restored insulin production, improved insulin resistance (IR), increased skeletal muscle glycogen content, and reduced systemic inflammation while modifying the gut microbiota.

To our knowledge, there is very little research focusing on the impact of GMP on oxidative stress (OxS) and inflammation pathways in enterocytes. Therefore, the major aim of this study is to determine whether GMP modulates OxS and inflammation, two central processes favoring IR using the well-established human-derived immortalized Caco-2/15 cell line. These intestinal cells spontaneously differentiate into polarized mature enterocytes under standard culture conditions and lend themselves to the in vitro study of human gut in view of its efficient intestinal transport processes [31].

\section{Materials and Methods}

\subsection{Caco-2/15 Cell Culture}

The human epithelial colorectal adenocarcinoma Caco-2/15 cell line, a stable clone of the parent Caco-2 cells (ATCC ${ }^{\circledR}$ HTB-37 ${ }^{\mathrm{TM}}$, American Type Culture Collection, Rockville, MD, USA), was obtained from Dr. JF Beaulieu (Department of Cellular Biology, Faculty of Medicine, Université de Sherbrooke, Sherbrooke, QC, Canada) [32,33]. Caco-2/15 cells were grown at $37{ }^{\circ} \mathrm{C}$ with $5 \% \mathrm{CO}_{2}$ in minimal essential medium (MEM) (GIBCO-BRL, Grand Island, NE, USA) containing $1 \%$ penicillin-streptomycin and $1 \%$ MEM nonessential amino acids (GIBCO BRL) and supplemented with $10 \%$ decomplemented fetal bovine serum (FBS) (Flow, McLean, VA, USA) as described previously [34]. Caco-2/15 cells were maintained in T-75- $\mathrm{cm}^{2}$ flasks (Corning Glass Works, Corning, NY, USA). Cultures were split (1:5) when they reached $70-90 \%$ confluence, by use of $0.05 \%$ trypsin- 0.5 mM EDTA (GIBCO-BRL). For individual experiments, cells were plated at a density of $1 \times 10^{6}$ cells/well on 6-well polycarbonate plates (Costar, Cambridge, MA, USA). Specifically, for lipoprotein assessment, cells were plated on 
24.5-mm polycarbonate Transwell filter inserts with 0.4- $\mu \mathrm{m}$ pores (Costar), in MEM (as described above) supplemented with 5\% FBS. The inserts were placed into six-well culture plates, permitting separate access to the apical and basolateral compartments of the monolayers. Cells were cultured for fourteen days at which point the Caco-2/15 cells are highly differentiated into polarized mature enterocytes and appropriate for lipid metabolism $[33,34]$. The medium was refreshed every other day.

\subsection{Caco 2/15 Cell Integrity}

Viability, morphology, and differentiation assays were performed to estimate Caco 2/15 cell integrity. Cell viability was evaluated with 3-(4,5-dimethyldiazol-2-yl)-2,5 diphenyl Tetrazolium Bromid (MTT, Sigma) after pre-treatment with different doses $(0.5,1$, and $2 \mathrm{mg} / \mathrm{mL}$ ) of purified GMP powder and incubation with $200 \mu \mathrm{M}$ iron (II) sulphate heptahydrate (Fe, Sigma-Aldrich, St Louis, MO, USA) and $2 \mathrm{mM}$ ascorbate (Asc, Sigma-Aldrich, St Louis, MO, USA) complex +/- GMP for $6 \mathrm{~h}$ at $37^{\circ} \mathrm{C}$ [33-35]. Following cell incubation, the medium was aspirated and replaced with an MTT solution $(0.5 \mathrm{mg} / \mathrm{mL})$. Incubation of cells for $2 \mathrm{~h}$ at $37^{\circ} \mathrm{C}$ with $5 \% \mathrm{CO}_{2}$ enables MTT oxidation by the succinate dehydrogenase enzyme in viable cells. The MTT solution was then aspirated and $500 \mu \mathrm{L}$ of dimethyl sulfoxide was added to each well to dissolve the resulting blue formazan crystals. The absorbance was measured at $535 \mathrm{~nm}$ with DMSO as a blank. Since $2 \mathrm{mg} / \mathrm{mL}$ of GMP caused no toxicity, this concentration was selected for the subsequent experiments. To estimate cellular differentiation and barrier integrity, villin, and occludin protein expression were assessed. Finally, monolayer intactness and physical barrier function were tested by evaluating morphology and transepithelial electric resistance [34].

\subsection{Induction of Oxidative Stress and Inflammation}

Fourteen days post confluence, the cells were washed twice with PBS and incubated in serum-free Eagle's minimal essential medium (EMEM) supplemented with $1 \%$ penicillin-streptomycin and $1 \%$ non-essential amino acid (NEAA) for $18 \mathrm{~h}$ in the presence or absence of GMP. Then after, the medium was removed, and cells were cultured with Fe/Asc in serum free EMEM supplemented with $1 \%$ penicillin-streptomycin and 1\% NEAA (pH 7.4) +/- GMP for $6 \mathrm{~h}$ at $37{ }^{\circ} \mathrm{C}$ to induce OxS and inflammation. This strong oxygen radical-generating system was employed to challenge cells and to evaluate their capacity to respond to an external pro-oxidant and pro-inflammatory stimulus as described previously [33-35].

\subsection{Insulin Pathways}

Following the same protocol above, two hours before the end of the six-hour incubation with $\mathrm{Fe} / \mathrm{Asc}$, insulin (Humulin R) was added at a final concentration of $100 \mathrm{nM}$ to evaluate the effect of the OxS on insulin sensitivity (IS) arising from signalization pathways [33].

\subsection{Malondiadehyde Measurement}

Estimation of lipid peroxidation was assessed by malondialdehyde (MDA) using a fluorescence detector HPLC as described previously [36-41].

\subsection{Protein Expression Analysis by Immunoblotting}

Following incubation with various treatments, Caco-2/15 cells were lysed in ice-cold buffer containing $20 \mathrm{mM}$ Tris- $\mathrm{HCl}$ (pH 7.4), $150 \mathrm{mM} \mathrm{NaCl}, 1 \mathrm{mM}$ Na2EDTA, 1 mM EGTA, 1\% NP-40, 1\% deoxycholate, $2.5 \mathrm{mM}$ sodium pyrophosphate, $1 \mathrm{mM} \mathrm{Na2VO}, 1 \mu \mathrm{g} / \mathrm{mL}$ leupeptin, and $1 \mathrm{mM}$ PMSF. Protein concentration of each sample was determined using the Bradford method (Bio-Rad). Proteins were then denatured for $5 \mathrm{~min}$ in sample buffer containing SDS and B-mercaptoethanol. Homogenates containing $15 \mu \mathrm{g}$ total proteins were separated on a 10\% SDS-polyacrylamide gel according to protein molecular weights and were electroblotted onto nitrocellulose membranes. Fat-free milk was used 
to block nonspecific sites of the membranes before adding primary antibodies overnight at $4{ }^{\circ} \mathrm{C}$ : villin (94 kDa, 1/1000, BD Biosciences); occludin (59 kDa, 1/1000, Abcam); tumor necrosis factor-alpha (TNF- $\alpha, 26 \mathrm{kDa}, 1 / 1000$, ThermoFisher scientific, Waltham, MA, USA); cyclooxygenase-2 (COX-2, $70 \mathrm{kDa}, 1 / 1000$, Novus); nuclear factor kappa-B (NF-kB, 65 kDa, 1/5000, Santa Cruz Biotechnology); nuclear factor erythroid-2-related factor 2 (NRF2, $110 \mathrm{kDa}, 1 / 1000$, Abcam); inhibitor of kappa B (IKB, $39 \mathrm{kDa}, 1 / 1000$, Cell Signaling Biotechnology); glutathione peroxidase 1 (GPx1, $26 \mathrm{kDa}, 1 / 1000$, Novus Biologicals); superoxide dismutase 2 (SOD2, $21 \mathrm{kDa}, 1 / 3000$, Invitrogen); phospho-Akt (p-Akt-Ser473, $60 \mathrm{kDa}, 1 / 1000$, ThermoFisher scientific); AKT (60 kDa, 1/1000, Cell signaling); p38 mitogen activated protein kinase (p38MAPK, $43 \mathrm{kDa}, 1 / 1000$, ThermoFisher scientific); phospho-p38 MAPK (43 kDa, 1/1000, Cell signaling); PI3 Kinase (PI3K, 85 kDa, 1/3000, Invitrogen); phospho PI3K p85 (85 kDA, 1/500, Abcam); AMP-activated protein kinase alpha (AMPK $\alpha$ and phospho AMPK $\alpha^{\text {Thr172 }}, 62 \mathrm{kDa}, 1 / 1000$, Cell signaling) and $\beta$-actin (43 kDa; $1 / 1000$, Sigma-Aldrich), as a housekeeping protein. Reactive bands were captured using a ChemiDoc MP Imaging System (Bio-Rad). All data are expressed as the ratio of target protein to $\beta$-actin in the same sample.

\subsection{Lipoprotein Assessment}

Cells were seeded at a density of $1 \times 10^{6} /$ well in six-well polycarbonate Transwell filter inserts plates (Costar Cambridge, MA, USA) containing $2.5 \mathrm{~mL}$ of culture medium in the basolateral compartment and $1.5 \mathrm{~mL}$ in the apical one. The culture medium was refreshed every 3 days. Fourteen days after seeding, cells were washed twice with PBS and supplied with $2.5 \mathrm{~mL}$ serum-free EMEM in the basolateral chamber, and $1.5 \mathrm{~mL}$ serum-free EMEM containing (BSA/oleic acid) (1:5, v:v, pH 7.4) in the apical chamber. GMP $(2 \mathrm{mg} / \mathrm{mL})$ was added to determine its effects on lipoprotein production. After $18 \mathrm{~h}$, the culture medium was discarded and replaced with fresh $2.5 \mathrm{~mL}$ serum-free EMEM and $1.5 \mathrm{~mL}$ radiolabeled $\left[{ }^{14} \mathrm{C}\right]$-oleic acid $(0.45 \mu \mathrm{Ci})(53 \mathrm{mCi} / \mathrm{mmol}$; Amersham, Oakville, ON, Canada) $\pm \mathrm{GMP}$ $(2 \mathrm{mg} / \mathrm{mL})$ in the basolateral and the apical compartments, respectively. After a $24 \mathrm{~h}$-incubation, media were collected from the two chambers and cells were washed twice with cold PBS and scraped in $1 \mathrm{~mL}$ of lysis buffer (1× TBS, pH 7.4; 5 mM EDTA; $0.1 \%$ SDS; $1 \%$ Triton $\times 100 ; 0.5 \%$ Sodium deoxycholate) containing $10 \mu \mathrm{L} / \mathrm{mL}$ of each anti-protease (PMSF, Leupeptin, and Pepstatin).

\subsection{Isolation of Lipoproteins}

Newly synthesized lipoproteins were separated from the basolateral medium supplemented with anti-proteases and plasma lipid carrier $(4: 1, v / v)$ to efficiently isolate de novo produced lipoproteins. Isolation was performed by sequential ultracentrifugation using a TL-100 ultracentrifuge as per our usual technique [33-35,38,42-44].

\subsection{Statistical Analysis}

All values are expressed as the mean \pm SEM of at least 3 different experiments carried out in triplicate. Data were analyzed by one-way ANOVA followed by the Tukey's multiple comparisons test using PRISM 7.0 (GraphPad Software, San Diego, CA, USA). Differences were considered significant at $p<0.05$.

\section{Results}

\subsection{Caco-215 Cell Integrity}

To ensure the consistency of our experiments, we first examined the integrity of Caco-2/15 following the addition of Fe/Asc and GMP. Compared to controls, no significant alterations were noted in cell viability using trypan blue staining and MTT assay, as described previously [34] after 24h-incubation (Figure 1A). We tested different doses $(0.5,1$, and $2 \mathrm{mg} / \mathrm{mL}$ ) for the MTT assay and $2 \mathrm{mg} / \mathrm{mL}$ was used for subsequent experiments as it did not alter cell viability and exerted the most beneficial effects on OxS (data not shown). Similarly, the barrier integrity and differentiation of 
Caco-2/15 cells were not modified as observed by the transepithelial electrical resistance, occludin and villin protein expression, respectively (Figure 1B-D). These results indicate that the administration of $\mathrm{Fe} /$ Asc and GMP do not exert cytotoxic effects on intestinal Caco-2/15 cells.

A

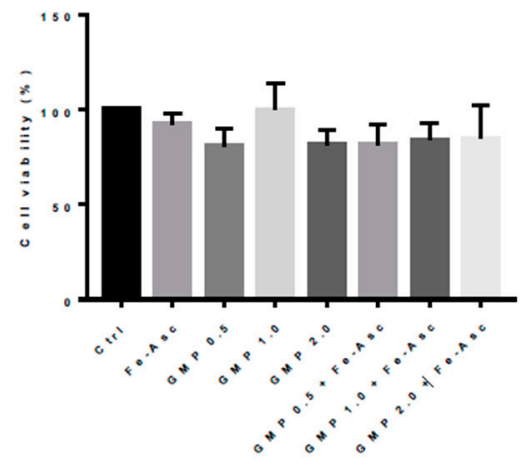

C

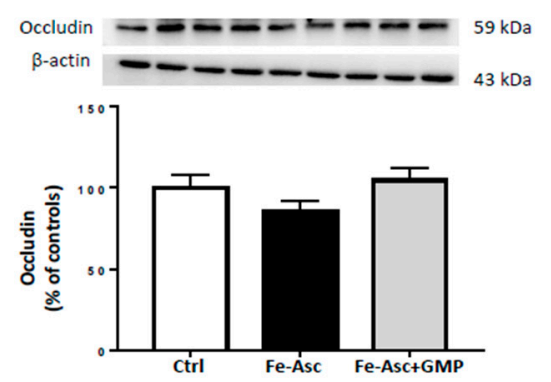

B
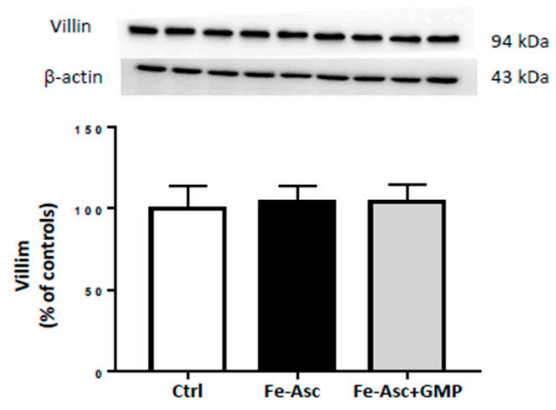

D

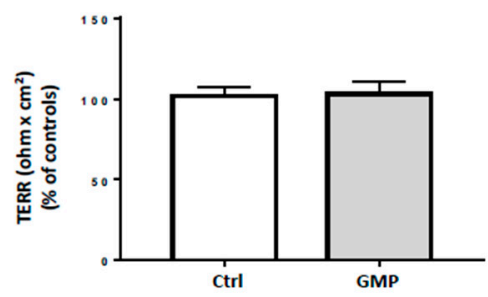

Figure 1. Effects of treatments on cell integrity in Caco-2/15 cells. Integrity of the cell monolayer was evaluated by cell viability, differentiation, and tight junction assays using fully differentiated Caco-2/15 cells. Different doses $(0.5,1$, and $2 \mathrm{mg} / \mathrm{mL}$ ) of purified glycomacropeptide (GMP) powder were added to Caco-2/15 cells $18 \mathrm{~h}$ before incubation with Fe/Asc $(200 \mu \mathrm{M} / 2 \mathrm{mM})$ for $6 \mathrm{~h}$ at $37^{\circ} \mathrm{C}$ for the (A) MTT assay. A dose of $2 \mathrm{mg} / \mathrm{mL}$ was selected for the assessment of (B) villin and (C) occludin protein expression as well as (D) transepithelial electrical resistance (TEER). Results represent the means \pm SEM of $n=3$ independent experiments in triplicate.

\subsection{Effects of Glycomacropeptide (GMP) on Lipid Peroxidation and Oxidative Stress (OxS)}

The extent of lipid peroxidation following the treatment of Caco-2/15 cells with Fe/Asc ( $200 \mu \mathrm{M}$, $2 \mathrm{mM}$ ) during $6 \mathrm{~h}$ was assessed to determine the malondialdehyde (MDA) levels [33]. HPLC analyses indicated a 10-fold increase in MDA following the administration of the oxygen free radical generating system Fe/Asc as compared with controls, and treatment with GMP strongly counteracted $\mathrm{Fe} /$ Asc-mediated lipid peroxidation (Figure 2A).

As failure of antioxidant defense may favour the induction of OxS, we examined the important endogenous antioxidant enzymes (SOD2, GPx). Treatment of Caco-2/15 cells with Fe/Asc caused a significant decrease in SOD2 protein expression with a slight drop of GPx. However, incubation with GMP blunted the Fe/Asc-mediated fall of SOD2 and upregulated GPx (Figure 2B,C), as well as restored NRF2, a critical transcription factor involved in cellular defense mechanisms against OxS (Figure 2D). 
A

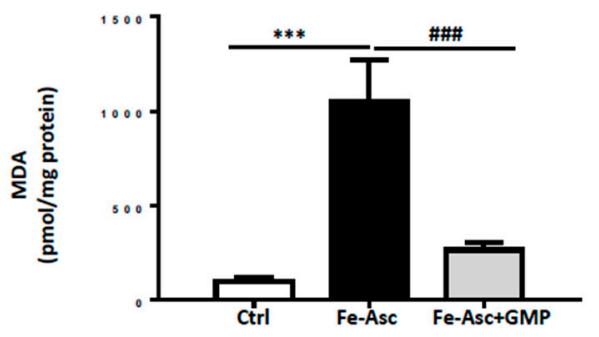

C

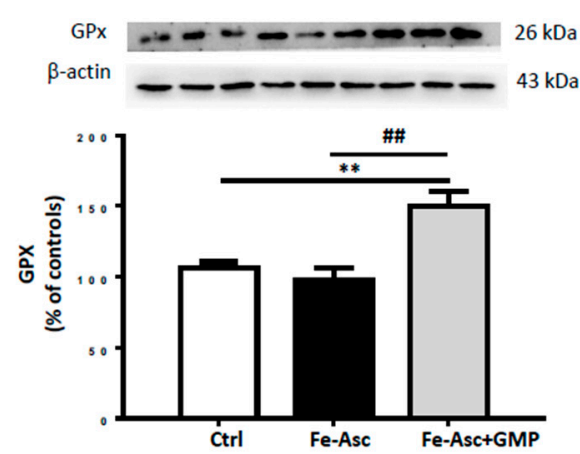

B
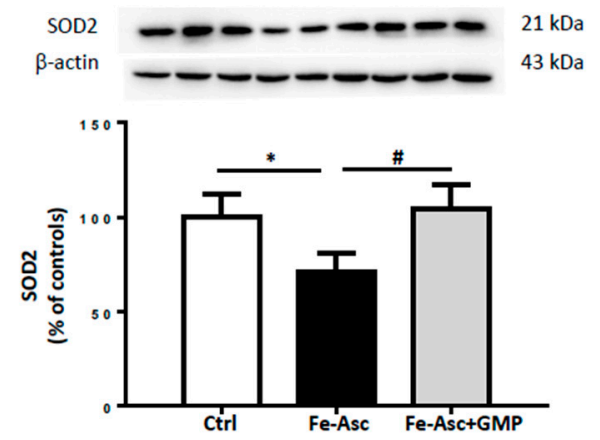

D
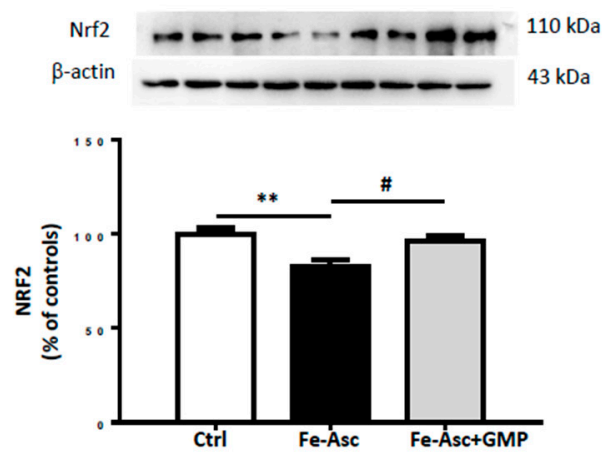

Figure 2. Effects of GMP on lipid peroxidation and antioxidant defense in Caco-2/15 cells. Caco-2/15 cells were pre-incubated for $18 \mathrm{~h}$ before treatment with Fe/Asc $(200 \mu \mathrm{M} / 2 \mathrm{mM})+/-\mathrm{GMP}(2 \mathrm{mg} / \mathrm{mL})$ for $6 \mathrm{~h}$ at $37^{\circ} \mathrm{C}$ as described in Materials and Methods. (A) Levels of malondialdehyde (MDA), a biomarker of lipid peroxidation, were measured in cell lysates. Protein expression of the anti-oxidative markers (B) superoxide dismutase 2 (SOD2), (C) glutathione peroxidase (GPx), and (D) nuclear factor erythroid 2-related factor 2 (Nrf2) was determined by Western blot. Results represent the means \pm SEM of $n=3$ independent experiments in triplicate. ${ }^{*} p<0.05,{ }^{* *} p<0.01,{ }^{* * *} p<0.001$ vs. controls (Ctrl). ${ }^{\#} p<0.05$, $\#$ \# $p<0.01, \ldots \#$ $p<0.001$ vs. Fe/Asc-treated cells.

\subsection{Effects of GMP on Inflammation}

The protein expression of TNF- $\alpha$, a powerful inflammatory mediator, was enhanced following the incubation of Caco-2/15 cells with Fe/Asc (Figure 3A). However, GMP-treated Caco-2/15 cells reduced TNF- $\alpha$ levels. As COX-2 amplifies and perpetuates the inflammatory condition by producing eicosanoids, its expression was also estimated by Western blot analysis. Our experiments showed that $\mathrm{Fe} /$ Asc elicited elevated COX-2 protein expression, which was dulled by GMP (Figure 3B). Moreover, Caco-2/15 cells exposed to Fe/Asc displayed a high protein expression of NF- $\mathrm{kB}$ as well as NF- $\mathrm{KB} / \mathrm{I} \mathrm{KB}$ ratio, which is indicative of an elevated transcriptional activation of its target inflammatory genes. GMP was found to blunt the activation of the NF- $\mathrm{kB}$ pathway in response to Fe/Asc (Figure 3C-E).

\subsection{Effects of GMP on Insulin Sensitivity Deriving from Insulin Signaling Pathways}

To investigate the impact of GMP on IS, the two main insulin signaling pathways were considered: the MAPKs and PI3K/AKT pathways $[45,46]$. Caco-2/15 cells were treated with insulin. Figure 4 shows that protein levels of phosphorylated forms of p38-MAPK and AKT were increased following $\mathrm{Fe} /$ Asc incubation whereas GMP displayed potency to prevent their activation (Figure 4B,E). A similar trend was noticed when the ratio was calculated (Figure 4C,F). However, insulin treatment caused no changes in total PI3K and AMPK protein expression (Figure 5A,D), but GMP downregulated PI3K and AMPK phosphorylation (Figure $5 \mathrm{~B}, \mathrm{E}$ ) as well as the calculated ratio (Figure 5C,F). 
A

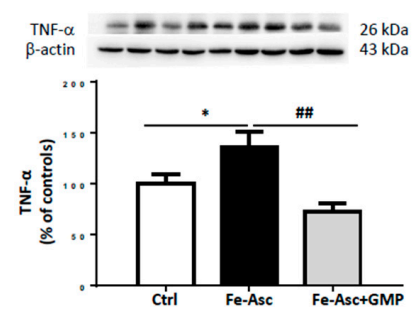

c
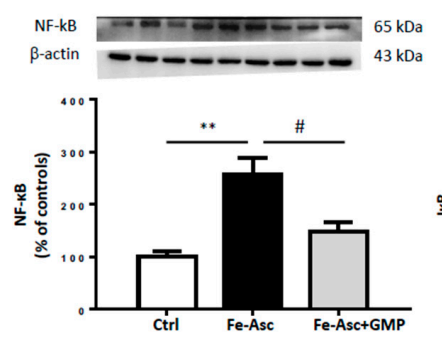

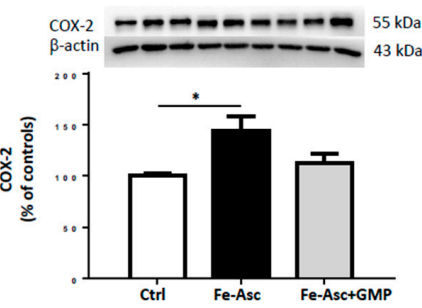

D

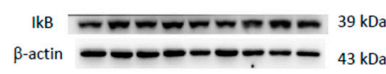

E

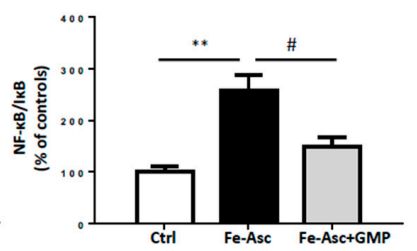

Figure 3. Effects of GMP on inflammation in Caco-2/15 cells. Caco-2/15 cells were pre-incubated for $18 \mathrm{~h}$ before treatment with Fe/Asc $(200 \mu \mathrm{M} / 2 \mathrm{mM})+/-$ GMP $(2 \mathrm{mg} / \mathrm{mL})$ for $6 \mathrm{~h}$ at $37^{\circ} \mathrm{C}$ as described in Materials and Methods. Protein expression of the inflammatory biomarkers (A) Tumor necrosis factor alpha (TNF- $\alpha$ ), (B) Cyclooxygenase-2 (COX-2), (C) Nuclear transcription factor-kappa B (NF-kB), and

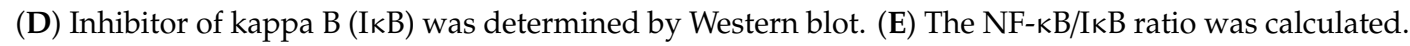
Results represent the means \pm SEM of $n=3$ independent experiments in triplicate. ${ }^{*} p<0.05,{ }^{* *} p<0.01$ vs. controls (Ctrl). ${ }^{\#} p<0.05,{ }^{\# \#} p<0.01$ vs Fe/Asc-treated cells.

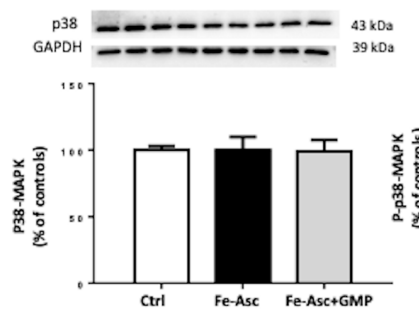

D

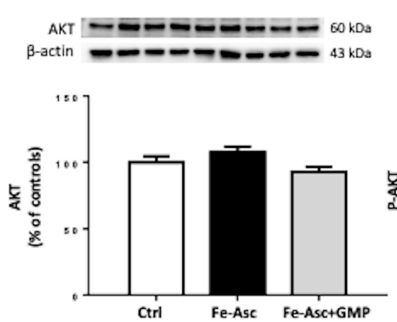

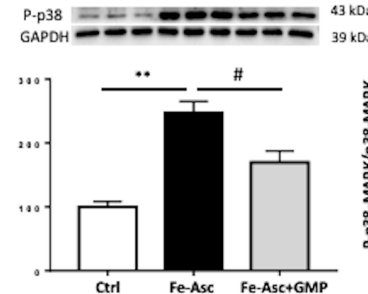

E

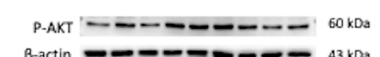

C

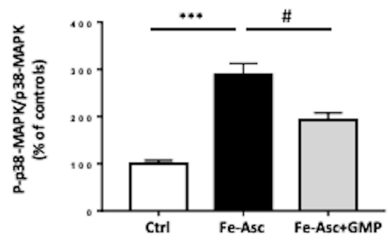

$\mathbf{F}$
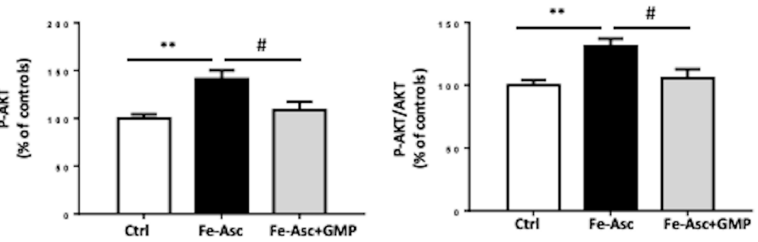

Figure 4. Effects of GMP on insulin sensitivity in Caco-2/15 cells. Caco-2/15 cells were pre-incubated for $18 \mathrm{~h}$ before treatment with Fe/Asc $(200 \mu \mathrm{M} / 2 \mathrm{mM})+/-\mathrm{GMP}(2 \mathrm{mg} / \mathrm{mL})$ for $6 \mathrm{~h}$ at $37^{\circ} \mathrm{C}$. Two hours before the end of the six hour-incubation with $\mathrm{Fe} / \mathrm{Asc}$, insulin $(100 \mathrm{nM})$ was added to evaluate insulin sensitivity as described in Materials and Methods. Protein expression of (A) p38-MAPK, (B) phospho-p38-MAPK, (D) AKT and (E) phospho-Akt was determined by Western blot. (C) Phospho p38-MAP/p38-MAPK and (F) phospho-Akt/AKT ratios were calculated. Results represent the means \pm SEM of $n=3$ independent experiments in triplicate. ${ }^{* *} p<0.01,{ }^{* * *} p<0.001$ vs. Controls (Ctr); ${ }^{\#} p<0.05$ vs. Fe/Asc Caco-2 cells treated with insulin. 


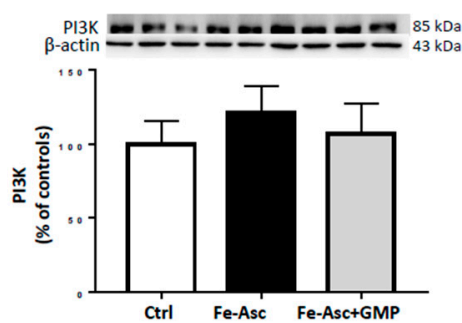

D

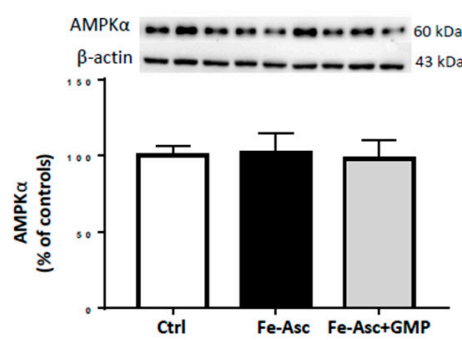

B

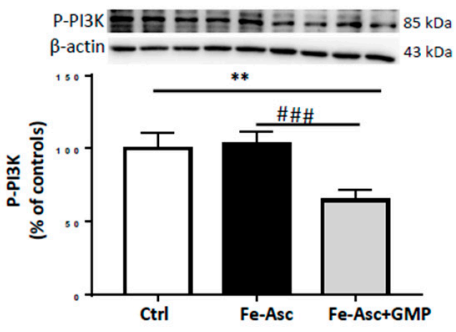

E

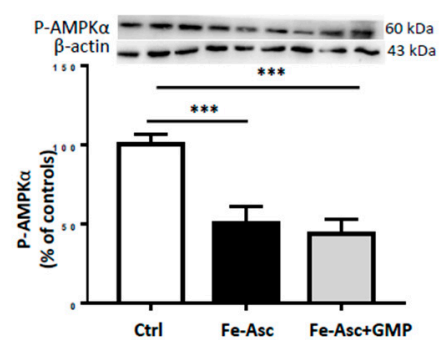

C

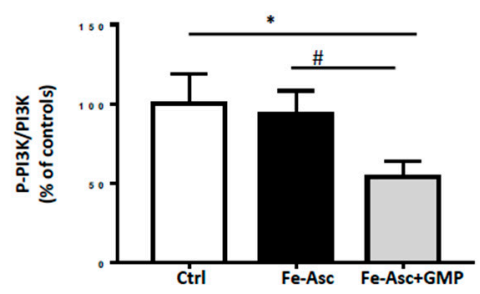

$\mathbf{F}$

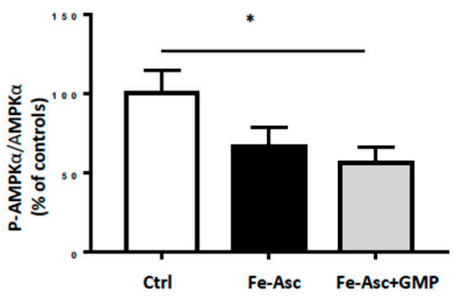

Figure 5. Effects of GMP on insulin signaling in Caco-2/15 cells. Caco-2/15 cells were pre-incubated for $18 \mathrm{~h}$ before treatment with Fe/Asc $(200 \mu \mathrm{M} / 2 \mathrm{mM})+/-$ GMP $(2 \mathrm{mg} / \mathrm{mL})$ for $6 \mathrm{~h}$ at $37^{\circ} \mathrm{C}$. Two hours before the end of the six hours incubation with Fe/Asc, insulin $(100 \mathrm{nM})$ was added to evaluate insulin signaling as described in Materials and Methods. Protein expression of (A) PI3K, (B) phospho-PI3K, (D) AMPK $\alpha$ and (E) phospho-AMPK $\alpha$ was determined by Western blot. (C) Phospho-PI3K/PI3K and (F) phospho-AMPK $\alpha / \mathrm{AMPK} \alpha$ ratios were calculated. Results represent the means \pm SEM of $n=3$ independent experiments in triplicate. ${ }^{*} p<0.05,{ }^{* *} p<0.01,{ }^{* * *} p<0.001$ vs. controls (Ctrl). ${ }^{*} p<0.05$, \#\#\# $p<0.001$ vs. Fe/Asc Caco-2 cells treated with insulin.

\subsection{Influence of GMP on Lipoprotein Production}

We further investigated the impact of GMP on lipoprotein production. Incubation of Caco-2/15 cells with oleic acid increased lipoprotein production of chylomicrons, very low-density lipoprotein (VLDL) and low-density lipoprotein (LDL) whereas the addition of GMP resulted in a reduced secretion of these lipoproteins (Figure 6).

A

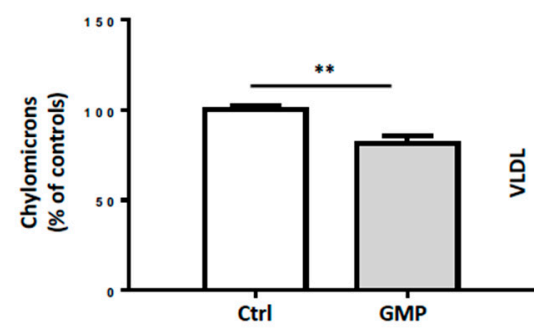

B

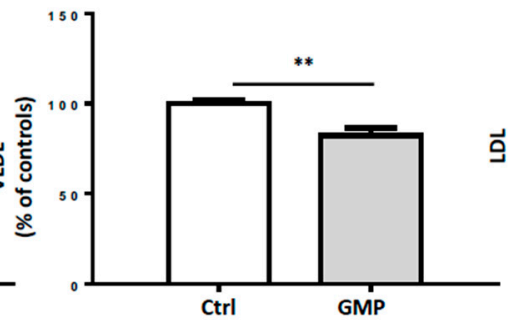

C

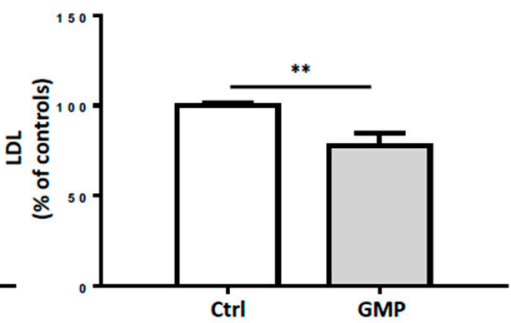

Figure 6. Effects of GMP on lipoprotein production in Caco-2/15 cells. Caco-2/15 cells were pre-incubated for $18 \mathrm{~h}$ with serum-free Eagle's minimal essential medium (EMEM) containing BSA/oleic acid +/GMP ( $2 \mathrm{mg} / \mathrm{mL})$. After $18 \mathrm{~h}$, medium was discarded and replaced with fresh EMEM and radiolabeled $\left[{ }^{14} \mathrm{C}\right]$-oleic acid +/- GMP (2 mg/mL). After $24 \mathrm{~h}$ incubation, apical and basolateral media were collected. Lipoprotein production was assessed by quantification of (A) chylomicrons, (B) very low-density lipoproteins (VLDL), and (C) low-density lipoproteins (LDL) in basolateral medium. Results represent the means \pm SEM of $n=3$ independent experiments in triplicate. ${ }^{* *} p<0.01$ vs. control (Ctrl) cells. 


\section{Discussion}

There is currently a growing interest in the use of dietary supplements and natural compounds to treat OxS and inflammation, two major processes contributing to the etiopathogenesis of many human chronic diseases. Although the health benefits of milk protein compounds are highlighted in many scientific reports, their impact on the gastrointestinal tract has not been investigated even if this system is central in cardiometabolic health homeostasis given its functional, physical, chemical, immunological, and microbiological properties. It is in this context that the present investigation has been undertaken. We could demonstrate that GMP, a milk-protein-derived peptide, is endowed with the potential to fight OxS, inflammation, intestinal lipoprotein production, and alterations of the insulin signaling pathways leading to postprandial dyslipidemia.

To examine the impact of GMP, we employed the Caco-2/15 cell line that undergoes a process of spontaneous differentiation leading to the formation of a monolayer of cells expressing several morphological and functional characteristics of the mature enterocyte $[47,48]$. As reported by our previous work, this remarkable intestinal model is regarded as the most appropriate for the investigation of gut absorption and interactions, nutrition, toxicology, food microbiology, bioavailability tests, and screening of drug permeability in discovery programs. Multiple studies from our laboratory $[2,31,35,43,49,50]$ and from other groups have shown that Caco-2/15 monolayers are fully appropriate for the study not only of lipid/lipoprotein homeostasis [30,31,42-44], but also OxS and inflammation $[35,40,41,51,52]$. In addition to the intestinal model, we used the efficient Fe/Asc complex that displays great ability to induce lipid peroxidation [37-40,51,53]. In fact, iron initiates strong lipid peroxidation via the Fenton reaction whereas ascorbic acid amplifies iron's oxidative potential by promoting metal ion-induced lipid peroxidation [51]. According to our previous studies, Fe/Asc not only generates reactive oxygen species (ROS), which strongly affect the prooxidant/antioxidant balance of the cell $[37-40,51]$ but it also elicits inflammation $[40,51]$. Therefore, our experimental conditions are appropriate to evaluate the antioxidant and anti-inflammatory properties of GMP. Nevertheless, as a prerequisite to the present study, it was necessary for us to demonstrate that Caco-2/15 cells maintain their full integrity following $\mathrm{Fe} / \mathrm{Asc}$ and GMP treatments. In line with our expectations, $\mathrm{Fe} / \mathrm{Asc}$ and GMP did not exert cytotoxic effects on intestinal Caco-2/15 cell wholeness as noted by an in-depth analysis of cell viability, barrier integrity, and differentiation.

As anticipated, treatment with $\mathrm{Fe} /$ Asc led to a significant increase in MDA, a major biomarker of lipid peroxidation, and to a marked decrease in SOD2 and GPx, two powerful antioxidant enzymes, which indicates perturbations of the prooxidant/antioxidant balance. On the other hand, GMP prevented lipid peroxidation probably by keeping the endogenous antioxidants from crumbling. To approach the mechanisms of action triggered by GMP, we determined the protein level of the transcription factor NRF2, orchestrating the cellular defense against OxS by controlling the expression of antioxidant genes and conferring cytoprotection against OxS $[40,41,54,55]$. Under basal conditions, NRF2 is in its inactive form since it is associated with kelch-like ECH-associated protein 1 (Keap1), which convenes it to proteasomal degradation [56]. However, in response to cellular stimuli, NRF2 dissociates from Keap1 and translocates to the nucleus [57] where it binds to the antioxidant response elements (ARE) in the promoter region of antioxidant genes, thereby leading to their upregulation [58]. Our data clearly evidence the effectiveness of GMP to avert Fe/Asc-mediated NRF2 diminution, which explains the recovery of antioxidant enzymes. Our findings are consistent with two previous studies reporting the attenuation of oxidative damage via NRF2 improvement in HEPG2 cells and RAW 264.7 macrophages with GMP hydrolysates [59,60]. NRF2 capacity to prevent OxS is well known, but more recently, it has also been suggested to play a protective role against CMD [55]. Notably, pharmacological activation of NRF2 in obese mice on high-fat high fructose diet reversed IR and suppressed hepatic steatosis [61]. Furthermore, administration of a synthetic activator of NRF2 (triterpenoid CDDO-Imidazolide) to high-fat fed mice led to decreased body weight, adipose masse and hepatic lipid accumulation [62] Therefore, GMP mediated activation of NRF2 might indicate a potential application in the treatment of CMD. 
Interestingly, GMP was also effective in depressing TNF- $\alpha$ and COX-2, two pro-inflammatory biomarkers in intestinal Caco-2/15 cells. As well evidenced by our findings, the mechanism for this GMP anti-inflammatory action is through the modulation of NF- $k B / I \kappa B$ pathway. In fact, GMP inhibited Fe/Asc-mediated NF-kB induction, which led to lower NF- $\mathrm{kB} / \mathrm{I} \kappa \mathrm{B}$ ratio. Therefore, GMP may be an important peptide to guard against inflammation that endangers intestinal cell functions by controlling NF- $\mathrm{kB}$, the master regulator of inflammatory response. Noteworthily, the upregulation of NRF2 may also contribute to the cellular defense against inflammation since dysregulation of NRF2 correlates with the development of chronic inflammatory diseases [63-66]. It is equally important to mention the crosstalk between OxS and inflammation processes $[67,68]$. For example, ROS can stimulate several inflammatory pathways through kinase activation and phosphorylation of NF- $\mathrm{kB}$ components $[67,68]$. On the other hand, NF- $\mathrm{KB}$ activation prevents NRF2 transcription by different mechanisms of action. In hepatocytes, it has been shown that overexpression of NF- $\mathrm{kB}$ p65 unit downregulates NRF2 transcription by competing with the same transcriptional co-activator CREB-binding protein (CBP)-p300 complex [69,70]. CBP-p300 plays a crucial role in histone acetylation, facilitating DNA transcription of histone, but also non histone proteins like NRF2 and p65 [69]. CBP-p300 has been shown to enhance the transcription of these target genes by adding an acetyl group on lysine residues of both transcription factors [70]. However, as CBP prioritizes NF- $\mathrm{kB}$ binding, it limits its availability for NRF2 [69]. Moreover, p65 may limit NRF2 transcription by promoting the recruitment of histone deacetylase 3, which associates with CBP [69]. Deacetylation of CBP prevents it from playing its co-activator role in NRF2, decreasing ARE-related gene expression [69]. Another proposed mechanism obtained from a hepatic cell line consists in p65 capacity to increase Keap1 levels [71]. This results in increase nuclear translocation of Keap1 and subsequent inactivation of NRF2. Those findings highlight the multiple pathways by which both OxS and inflammation influence each other. Studies are still required to explore how GMP targets these OxS-inflammation close interactions. As OxS and inflammation are key inducers of IR and other metabolic affections of the Metabolic Syndrome (MetS) [72-75], we decided to evaluate GMP's capacity to regulate some key proteins of the insulin signaling pathway. We first focused on p38 MAPK that is activated by OxS and interferes with the insulin receptor signaling cascade [76,77]. Measurement of p38-MAPK phosphorylation and analysis of phospho-p38-MAPK/p38-MAPK ratio revealed a significant increase, which is compatible with reduced IS in Caco-2/15 cells. However, GMP displayed the ability to restore the values of p38 MAPK phosphorylation and phospho-p38 MAPK/p38 MAPK ratio to normal.

Thereafter, we turned to the PI3K/AKT signaling pathway that normally mediates the major biological effects of insulin by regulating glucose transport, protein synthesis, gluconeogenesis, cellular proliferation, and cell survival [78,79]. Instead, its abnormality directly results in IR [80]. Surprisingly, our experiments revealed a stimulation of the phosphorylation of PI3K/AKT by Fe/Asc, which returned back to normal with GMP administration. The impact of Fe/Asc-mediated lipid peroxidation on PI3K/AKT signaling is hitherto unknown in intestinal cells and comparisons are virtually impossible. A few studies have attempted to explain the mechanism of action by which OxS stimulates AKT signaling pathway. In DT40 cells, $\mathrm{H}_{2} \mathrm{O}_{2}$ was found to promote PI3K membrane recruitment to its substrate site, increasing PI3K catalytic function and AKT activation [81]. In glioblastoma cell line, $\mathrm{H}_{2} \mathrm{O}_{2}$ increases AKT phosphorylation via the upstream activation of focal adhesion kinase, a protein kinase involved in cellular adhesion which associates with PI3K [82]. In Hela cells, AKT activation is dependent of $\mathrm{H}_{2} \mathrm{O}_{2}$ stimulation of epidermal growth factor receptor [83]. Those different mechanisms of action highlight the numerous ways by which OxS can stimulate AKT, which are probably cell specific. However, more studies are needed in order to determine the exact mechanism of action by which Fe/Asc stimulates AKT in intestinal cells.

The explanation for our data appears to rest on the fact that AKT is involved in multiple signaling pathways other than insulin signaling such as cell survival, proliferation, metabolism, growth, and others [84]. AKT is particularly important for cell survival as it mediates important anti-apoptotic functions, limiting cell death induced by growth factor withdrawal, cell cycle discordance, and 
detachment of cells from their extracellular matrix [85]. However, conflicting data exist concerning the influence of OxS on AKT. Several studies have shown that OxS induced by pesticides in Caco-2 cells [86], UV irradiation (ASTC1 cells) [87], and hyperosmotic stress (kidney cells) [88] led to decreased AKT activity. However, other studies have shown that OxS induced by oxidant injury or other environmental stresses activate AKT [89-91]. For example, rat intestinal epithelial cells submitted to $\mathrm{H}_{2} \mathrm{O}_{2}$ results in increased AKT phosphorylation [92]. Similarly, $\mathrm{H}_{2} \mathrm{O}_{2}$ administration to hepatocytes induces ROS accumulation and increases AKT activity [93]. This discrepancy in AKT regulation seems to originate from the identity, intensity and persistence of the stress signal and the resulting fate of the cell. In studies where OxS was found to decrease AKT phosphorylation, cell apoptosis was also reported [86,87]. In contrast, in studies where OxS increased AKT phosphorylation, cell survival was instead promoted $[82,83,92]$. From those observations, several authors have put forward the idea that AKT downregulation is essential to the apoptotic process [85]. Since we demonstrated that Fe/Asc does not curtail cell viability (Figure 1), the enhanced AKT phosphorylation found in our investigation might indicate that $\mathrm{Fe} / \mathrm{Asc}$ stimulates defense mechanisms against $\mathrm{OxS}$ and apoptosis in intestinal cells, which are mediated by AKT signaling pathway. Nevertheless, in most of the cases, GMP showed a tendency to bring the values of Fe/Asc-mediated insulin signaling factors closer to the control levels.

Since $\mathrm{Fe} / \mathrm{Asc}$ is a pro-oxidant similar to $\mathrm{H}_{2} \mathrm{O}_{2}$ which induces ROS accumulation and antioxidant depletion, we hypothesize that the increase in AKT phosphorylation found in our results is indicative of a mechanism of resistance to OxS rather than a mechanism of IS. AKT also promotes cell survival by preventing the release of cytochrome c from the mitochondria [94]. Therefore, the enhanced phosphorylation of AKT in response to Fe/Asc in our study may reflect increased cellular defense mechanisms rather than stimulation of IS, which is consistent with similar outcomes following OxS and inflammation in other cellular models as demonstrated above $[92,93,95]$. Therefore, lower phosphorylation levels of AKT observed with GMP treatment may indicate a positive role of GMP against OxS and inflammation. This is supported by a previous study where GMP hydrolysates supplementation was also found to decrease AKT activity in lipopolysaccharides-stimulated RAW 264.7 macrophage [96]. Similar to our results, it was accompanied by a decrease in levels of malondialdehyde, ROS production and pro-inflammatory markers (NF-kB, COX-2, and phospho-p38-MAPK) [96]. Interestingly, the authors suggested that AKT phosphorylation could be involved in NF-kB activation, as it had been previously been demonstrated elsewhere $[97,98]$. Since we also found an increase in both AKT phosphorylation and NF-kB in our study, this mechanism of action is also a plausible signaling pathway. Although the literature is very sparse regarding the impact of iron on AKT signaling in intestinal cells, investigations conducted in other cell types can provide insight about its known effects. Studies conducted in neuroblastomas, hepatic macrophages, cerebral cortex synaptic endings and neurons, show that iron administration increases AKT activity in response to OxS [99-102]. Similar to our results, neurons exposed to iron display increased lipid peroxidation without alteration of cellular viability [103]. The authors reported that in response to OxS, AKT translocated to the nucleus and modulated glycogen synthase kinase $3 \beta$ phosphorylation, Forkhead box $\mathrm{O}$ transcriptional activity, and glutathione metabolism that resulted in increased resistance to OxS [103]. Moreover, another study evidenced that iron deficiency downregulates AKT phosphorylation in rats and in COS-1 cells, leading to a decrease in mammalian target of rapamycin activity [104]. In line with this, in intestinal Caco 2 cells, iron depletion was also shown to depress AKT activity, whereas iron repletion restored AKT levels [105]. Therefore, it is reasonable to believe that the results obtained in our investigation might result from ROS accumulation induced by Fe treatment or by Fe activity itself.

We also assessed AMPK, a critical energy sensor and a well-known central regulator of energy metabolism. First, we noticed that the addition of insulin for the assessment of the insulin receptor signaling cascade resulted in decreased phosphorylation of AMPK, which has also been reported in diverse cellular models such as hepatocytes and hearts of rats [106,107]. Some authors suggested a direct inhibitory effect on AMPK, whereas others proposed an indirect impact [108-110]. In fact, 
different investigators insinuate that AMPK is phosphorylated on its inhibitory site (Ser 485/491) by AKT, which prevents its subsequent phosphorylation and activation on Th172 [111-113].

As GMP was observed to lessen OxS and inflammation, both known to induce lipid/lipoprotein disorders, we assessed the influence of GMP on lipoprotein output in Caco-2/15 cells. Our results revealed that GMP was effective in lowering the secretion of chylomicrons, VLDL, and LDL, suggesting its potency to prevent postprandial dyslipidemia and therefore CMD.

In summary, the present investigation demonstrates the capacity of GMP to improve IS and dyslipidemia, two major components of the MetS. GMP showed also beneficial effects on insulin signalization pathways and lipoprotein production. Therefore, GMP may represent a new preventive/therapeutic strategy to ameliorate metabolic disorders.

Author Contributions: Conceptualization, E.L.; Methodology, E.L.; Validation, M.F.-S., L.A. and A.T.S.; Formal Analysis, M.F.-S., S.S. and E.L.; Resources, E.L.; Data Curation, M.F.-S.; Writing-Original Draft Preparation, M.F.-S. and E.L.; Writing-Review \& Editing, M.F.-S., S.S., E.D. and E.L.; Visualization, E.L.; Supervision, E.L.; Funding Acquisition, E.L. All authors have read and agreed to the published version of the manuscript.

Funding: This research was funded by the Dairy Farmers of Canada (E4839) and the JA deSève Research Chair in nutrition. M.F.-S. received a FRQS/CIHR Master Scholarship Award.

Conflicts of Interest: The authors declare no conflict of interest.

\section{Abbreviations}

$\begin{array}{ll}\text { AMPK } & \text { AMP-activated protein kinase } \\ \text { ARE } & \text { Antioxidant response elements } \\ \text { CBP } & \text { CREB-binding protein } \\ \text { CM } & \text { Chylomicron } \\ \text { CMD } & \text { Cardiometabolic disorders } \\ \text { COX-2 } & \text { Cyclooxygenase-2 } \\ \text { EMEM } & \text { Eagle's minimal essential medium } \\ \text { FBS } & \text { fetal bovine serum } \\ \text { Fe/Asc } & \text { Iron-ascorbate } \\ \text { GI } & \text { Gastrointestinal } \\ \text { GMP } & \text { Glycomacropeptide } \\ \text { GPx } & \text { Glutathione peroxidase 1 } \\ \text { IkB } & \text { Inhibitor of kappa B } \\ \text { IS } & \text { Insulin sensitivity } \\ \text { IR } & \text { insulin resistance } \\ \text { Keap1 } & \text { Kelch-like ECH-associated protein 1 } \\ \text { LDL } & \text { Low-density lipoprotein } \\ \text { MDA } & \text { Malondialdehyde } \\ \text { MEM } & \text { minimal essential medium } \\ \text { MetS } & \text { Metabolic syndrome } \\ \text { MAPK } & \text { Mitogen activated protein kinase } \\ \text { NEAA } & \text { non-essential amino acid } \\ \text { NF-kB } & \text { Nuclear transcription factor-kappa B } \\ \text { NRF2 } & \text { Nuclear factor erythroid 2-related factor 2 } \\ \text { OxS } & \text { Oxidative stress } \\ \text { ROS } & \text { Reactive oxygen species } \\ \text { p-Akt } & \text { Phospho-protein kinase B } \\ \text { p38-MAPK } & \text { p38 mitogen activated protein kinase } \\ \text { SOD2 } & \text { Superoxide dismutase 2 } \\ \text { TNF- } \alpha & \text { Tumor necrosis factor alpha } \\ \text { VLDL } & \text { Very-low-density lipoprotein } \\ & \end{array}$




\section{References}

1. Anhe, F.F.; Roy, D.; Pilon, G.; Dudonne, S.; Matamoros, S.; Varin, T.V.; Garofalo, C.; Moine, Q.; Desjardins, Y.; Levy, E.; et al. A polyphenol-rich cranberry extract protects from diet-induced obesity, insulin resistance and intestinal inflammation in association with increased Akkermansia spp. population in the gut microbiota of mice. Gut 2015, 64, 872-883. [CrossRef] [PubMed]

2. Levy, E. Insights from human congenital disorders of intestinal lipid metabolism. J. Lipid Res. 2015, 56, 945-962. [CrossRef] [PubMed]

3. Bujko, A.; Atlasy, N.; Landsverk, O.J.B.; Richter, L.; Yaqub, S.; Horneland, R.; Oyen, O.; Aandahl, E.M.; Aabakken, L.; Stunnenberg, H.G.; et al. Transcriptional and functional profiling defines human small intestinal macrophage subsets. J. Exp. Med. 2018, 215, 441-458. [CrossRef] [PubMed]

4. Drucker, D.J. The role of gut hormones in glucose homeostasis. J. Clin. Investig. 2007, 117, 24-32. [CrossRef] [PubMed]

5. Valassi, E.; Scacchi, M.; Cavagnini, F. Neuroendocrine control of food intake. Nutr. Metab. Cardiovasc. Dis. 2008, 18, 158-168. [CrossRef]

6. Cani, P.D. Interactions between gut microbes and host cells control gut barrier and metabolism. Int. J. Obes. Suppl. 2016, 6, S28-S31. [CrossRef]

7. Schauer, P.R.; Bhatt, D.L.; Kirwan, J.P.; Wolski, K.; Aminian, A.; Brethauer, S.A.; Navaneethan, S.D.; Singh, R.P.; Pothier, C.E.; Nissen, S.E.; et al. Bariatric surgery versus intensive medical therapy for diabetes-5-year outcomes. N. Engl. J. Med. 2017, 376, 641-651. [CrossRef]

8. Ricci-Cabello, I.; Olalla Herrera, M.; Artacho, R.J.N.R. Possible role of milk-derived bioactive peptides in the treatment and prevention of metabolic syndrome. Nutr. Rev. 2012, 70, 241-255. [CrossRef]

9. Hernández-Ledesma, B.; García-Nebot, M.J.; Fernández-Tomé, S.; Amigo, L.; Recio, I. Dairy protein hydrolysates: Peptides for health benefits. Int. Dairy J. 2014, 38, 82-100. [CrossRef]

10. McGregor, R.A.; Poppitt, S.D. Milk protein for improved metabolic health: A review of the evidence. Nutr. Metab. 2013, 10, 46. [CrossRef]

11. Nagpal, R.; Behare, P.; Rana, R.; Kumar, A.; Kumar, M.; Arora, S.; Morotta, F.; Jain, S.; Yadav, H.J.F. Bioactive peptides derived from milk proteins and their health beneficial potentials: An update. Food Funct. 2011, 2, 18-27. [CrossRef] [PubMed]

12. Ballard, O.; Morrow, A.L. Human milk composition: Nutrients and bioactive factors. Pediatric Clin. 2013, 60, 49-74.

13. Vargas-Bello-Perez, E.; Marquez-Hernandez, R.I.; Hernandez-Castellano, L.E. Bioactive peptides from milk: Animal determinants and their implications in human health. J. Dairy Res. 2019, 86, 136-144. [CrossRef] [PubMed]

14. Brody, E.P. Biological activities of bovine glycomacropeptide. Br. J. Nutr. 2000, 84 (Suppl. 1), S39-S46. [CrossRef]

15. Zimecki, M.; Kruzel, M.L. Milk-derived proteins and peptides of potential therapeutic and nutritive value. J. Exp. Ther. Oncol. 2007, 6, 89-106.

16. O'Riordan, N.; Kane, M.; Joshi, L.; Hickey, R.M.J.G. Structural and functional characteristics of bovine milk protein glycosylation. Glycobiology 2014, 24, 220-236. [CrossRef]

17. Chabance, B.; Marteau, P.; Rambaud, J.; Migliore-Samour, D.; Boynard, M.; Perrotin, P.; Guillet, R.; Jolles, P.; Fiat, A.J.B. Casein peptide release and passage to the blood in humans during digestion of milk or yogurt. Biochimie 1998, 80, 155-165. [CrossRef]

18. Strömqvist, M.; Falk, P.; Bergström, S.; Hansson, L.; Lönnerdal, B.; Normark, S.; Hernell, O. Human milk kappa-casein and inhibition of Helicobacter pylori adhesion to human gastric mucosa. J. Pediatric Gastroenterol. Nutr. 1995, 21, 288-296. [CrossRef]

19. Azuma, N.; Yamauchi, K. A glyco-phosphoprotein in human milk. J. Dairy Res. 1987, 54, 199-205. [CrossRef]

20. Kawasaki, Y.; Isoda, H.; Tanimoto, M.; Dosako, S.; Idota, T.; Ahiko, K. Inhibition by lactoferrin and kappa-casein glycomacropeptide of binding of Cholera toxin to its receptor. Biosci. Biotechnol. Biochem. 1992, 56, 195-198. [CrossRef]

21. Guilloteau, P.; Rome, V.; Delaby, L.; Mendy, F.; Roger, L.; Chayvialle, J.A. Is caseinomacropeptide from milk proteins, an inhibitor of gastric secretion? Regul. Pept. 2010, 159, 129-136. [CrossRef] [PubMed] 
22. Feeney, S.; Ryan, J.T.; Kilcoyne, M.; Joshi, L.; Hickey, R. Glycomacropeptide Reduces Intestinal Epithelial Cell Barrier Dysfunction and Adhesion of Entero-Hemorrhagic and Entero-Pathogenic Escherichia coli in Vitro. Foods 2017, 6, 93. [CrossRef] [PubMed]

23. Daddaoua, A.; Puerta, V.; Zarzuelo, A.; Suarez, M.D.; Sanchez de Medina, F.; Martinez-Augustin, O. Bovine glycomacropeptide is anti-inflammatory in rats with hapten-induced colitis. J. Nutr. 2005, 135, 1164-1170. [CrossRef]

24. Requena, P.; Daddaoua, A.; Martínez-Plata, E.; González, M.; Zarzuelo, A.; Suárez, M.D.; Sánchez de Medina, F.; Martínez-Augustin, O. Bovine glycomacropeptide ameliorates experimental rat ileitis by mechanisms involving downregulation of interleukin 17. Br. J. Pharmacol. 2008, 154, 825-832. [CrossRef] [PubMed]

25. Mikkelsen, T.L.; Bakman, S.; Sørensen, E.S.; Barkholt, V.; Frøkiær, H.; Chemistry, F. Sialic acid-containing milk proteins show differential immunomodulatory activities independent of sialic acid. J. Agric. Food Chem. 2005, 53, 7673-7680. [CrossRef]

26. Li, E.W.; Mine, Y.J.; Chemistry, F. Immunoenhancing effects of bovine glycomacropeptide and its derivatives on the proliferative response and phagocytic activities of human macrophagelike cells, U937. J. Agric. Food Chem. 2004, 52, 2704-2708. [CrossRef]

27. Otani, H.; Horimoto, Y.; Monnai, M.J.B. Suppression of interleukin-2 receptor expression on mouse CD4 ${ }^{+} \mathrm{T}$ cells by bovine K-caseinoglycopeptide. Biosci. Biotechnol. Biochem. 1996, 60, 1017-1019. [CrossRef]

28. Royle, P.J.; McIntosh, G.H.; Clifton, P.M. Whey protein isolate and glycomacropeptide decrease weight gain and alter body composition in male Wistar rats. Br. J. Nutr. 2008, 100, 88-93. [CrossRef]

29. Xu, S.; Mao, X.; Cheng, X.; Chen, B. Ameliorating effects of casein glycomacropeptide on obesity induced by high-fat diet in male Sprague-Dawley rats. Food Chem. Toxicol. 2013, 56, 1-7. [CrossRef]

30. Yuan, Q.; Zhan, B.; Chang, R.; Du, M.; Mao, X.J.N. Antidiabetic Effect of Casein Glycomacropeptide Hydrolysates on High-Fat Diet and STZ-Induced Diabetic Mice via Regulating Insulin Signaling in Skeletal Muscle and Modulating Gut Microbiota. Nutrients 2020, 12, 220. [CrossRef]

31. Levy, E.; Mehran, M.; Seidman, E. Caco-2 cells as a model for intestinal lipoprotein synthesis and secretion. FASEB J. 1995, 9, 626-635. [CrossRef] [PubMed]

32. Beaulieu, J.F.; Quaroni, A. Clonal analysis of sucrase-isomaltase expression in the human colon adenocarcinoma Caco-2 cells. Biochem. J. 1991, 280 Pt 3, 599-608. [CrossRef]

33. Sane, A.; Ahmarani, L.; Delvin, E.; Auclair, N.; Spahis, S.; Levy, E. SAR1B GTPase is necessary to protect intestinal cells from disorders of lipid homeostasis, oxidative stress, and inflammation. J. Lipid Res. 2019, 60, 1755-1764. [CrossRef] [PubMed]

34. Kleme, M.L.; Sane, A.; Garofalo, C.; Seidman, E.; Brochiero, E.; Berthiaume, Y.; Levy, E. CFTR Deletion Confers Mitochondrial Dysfunction and Disrupts Lipid Homeostasis in Intestinal Epithelial Cells. Nutrients 2018, 10, 836. [CrossRef] [PubMed]

35. Levy, E.; Trudel, K.; Bendayan, M.; Seidman, E.; Delvin, E.; Elchebly, M.; Lavoie, J.-C.; Precourt, L.-P.; Amre, D.; Sinnett, D.J.; et al. Biological role, protein expression, subcellular localization, and oxidative stress response of paraoxonase 2 in the intestine of humans and rats. Am. J. Physiol.-Gastrointest. Liver Physiol. 2007, 293, G1252-G1261. [CrossRef] [PubMed]

36. Kleme, M.L.; Sane, A.T.; Garofalo, C.; Levy, E. Targeted CFTR gene disruption with zinc-finger nucleases in human intestinal epithelial cells induces oxidative stress and inflammation. Int. J. Biochem. Cell Biol. 2016, 74, 84-94. [CrossRef] [PubMed]

37. Taha, R.; Seidman, E.; Mailhot, G.; Boudreau, F.; Gendron, F.-P.; Beaulieu, J.-F.; Menard, D.; Delvin, E.; Amre, D.; Levy, E.J.P.O. Oxidative stress and mitochondrial functions in the intestinal Caco-2/15 cell line. PLoS ONE 2010, 5, e11817. [CrossRef]

38. Marcil, V.; Seidman, E.; Sinnett, D.; Boudreau, F.; Gendron, F.-P.; Beaulieu, J.-F.; Ménard, D.; Precourt, L.-P.; Amre, D.; Levy, E. Modification in oxidative stress, inflammation, and lipoprotein assembly in response to hepatocyte nuclear factor $4 \alpha$ knockdown in intestinal epithelial cells. J. Biol. Chem. 2010, 285, 40448-40460. [CrossRef]

39. Courtois, F.; Seidman, E.G.; Delvin, E.; Asselin, C.; Bernotti, S.; Ledoux, M.; Levy, E.J. Membrane peroxidation by lipopolysaccharide and iron-ascorbate adversely affects Caco-2 cell function: Beneficial role of butyric acid. Am. J. Clin. Nutr. 2003, 77, 744-750. [CrossRef] 
40. Denis, M.C.; Furtos, A.; Dudonne, S.; Montoudis, A.; Garofalo, C.; Desjardins, Y.; Delvin, E.; Levy, E.J.P.O. Apple peel polyphenols and their beneficial actions on oxidative stress and inflammation. PLoS ONE 2013,8, e53725. [CrossRef]

41. Denis, M.-C.; Desjardins, Y.; Furtos, A.; Marcil, V.; Dudonné, S.; Montoudis, A.; Garofalo, C.; Delvin, E.; Marette, A.; Levy, E.J. Prevention of oxidative stress, inflammation and mitochondrial dysfunction in the intestine by different cranberry phenolic fractions. Clin. Sci. 2015, 128, 197-212. [CrossRef] [PubMed]

42. Delvin, E.; Sane, A.; Tremblay, E.; Garofalo, C.; Levy, E.; Grenier, E.; Maupas, F.S.; Beaulieu, J.-F.; Seidman, E. Effect of retinoic acid on cell proliferation and differentiation as well as on lipid synthesis, lipoprotein secretion, and apolipoprotein biogenesis. Am. J. Physiol.-Gastrointest. Liver Physiol. 2007, 293, G1178-G1189.

43. Sané, A.T.; Sinnett, D.; Delvin, E.; Bendayan, M.; Marcil, V.; Ménard, D.; Beaulieu, J.-F.; Levy, E. Localization and role of NPC1L1 in cholesterol absorption in human intestine. J. Lipid Res. 2006, 47, 2112-2120. [CrossRef] [PubMed]

44. Sané, A.T.; Seidman, E.; Peretti, N.; Kleme, M.L.; Delvin, E.; Deslandres, C.; Garofalo, C.; Spahis, S.; Levy, E.J.A. Understanding chylomicron retention disease through Sar1b Gtpase gene disruption: Insight from cell culture. Arterioscler. Thromb. Vasc. Biol. 2017, 37, 2243-2251. [CrossRef] [PubMed]

45. Guo, S. Insulin signaling, resistance, and the metabolic syndrome: Insights from mouse models into disease mechanisms. J. Endocrinol. 2014, 220, T1-T23. [CrossRef]

46. Lauterbach, M.A.; Wunderlich, F.T. Macrophage function in obesity-induced inflammation and insulin resistance. Pflügers Arch.-Eur. J. Physiol. 2017, 469, 385-396. [CrossRef]

47. Bailey, C.A.; Bryla, P.; Malick, A.W. The use of the intestinal epithelial cell culture model, Caco-2, in pharmaceutical development. Adv. Drug Deliv. Rev. 1996, 22, 85-103. [CrossRef]

48. Shah, P.; Jogani, V.; Bagchi, T.; Misra, A. Role of Caco-2 cell monolayers in prediction of intestinal drug absorption. Biotechnol. Prog. 2006, 22, 186-198. [CrossRef]

49. Grenier, E.; Garofalo, C.; Delvin, E.; Levy, E.J.P.o. Modulatory role of PYY in transport and metabolism of cholesterol in intestinal epithelial cells. PLoS ONE 2012, 7, e40992. [CrossRef]

50. Ravid, Z.; Bendayan, M.; Delvin, E.; Sané, A.T.; Elchebly, M.; Lafond, J.; Lambert, M.; Mailhot, G.; Levy, E.; Physiology, L. Modulation of intestinal cholesterol absorption by high glucose levels: Impact on cholesterol transporters, regulatory enzymes, and transcription factors. Am. J. Physiol.-Gastrointest. Liver Physiol. 2008, 295, G873-G885. [CrossRef]

51. Bernotti, S.; Seidman, E.; Sinnett, D.; Brunet, S.; Dionne, S.; Delvin, E.; Levy, E.J.; Physiology, L. Inflammatory reaction without endogenous antioxidant response in Caco-2 cells exposed to iron/ascorbate-mediated lipid peroxidation. Am. J. Physiol.-Gastrointest. Liver Physiol. 2003, 285, G898-G906. [CrossRef] [PubMed]

52. Precourt, L.-P.; Seidman, E.; Delvin, E.; Amre, D.; Deslandres, C.; Dominguez, M.; Sinnett, D.; Levy, E. Comparative expression analysis reveals differences in the regulation of intestinal paraoxonase family members. Int. J. Biochem. Cell Biol. 2009, 41, 1628-1637. [CrossRef] [PubMed]

53. Tsikas, D. Assessment of lipid peroxidation by measuring malondialdehyde (MDA) and relatives in biological samples: Analytical and biological challenges. Anal. Biochem. 2017, 524, 13-30. [CrossRef] [PubMed]

54. Jaiswal, A.K. Nrf2 signaling in coordinated activation of antioxidant gene expression. Free Radic. Biol. Med. 2004, 36, 1199-1207. [CrossRef] [PubMed]

55. Vasileva, L.V.; Savova, M.S.; Amirova, K.M.; Dinkova-Kostova, A.T.; Georgiev, M.I. Obesity and NRF2-mediated cytoprotection: Where is the missing link? Pharmacol. Res. 2020, 156, 104760. [CrossRef] [PubMed]

56. Kensler, T.W.; Wakabayashi, N.; Biswal, S. Cell survival responses to environmental stresses via the Keap1-Nrf2-ARE pathway. Annu. Rev. Pharmacol. Toxicol. 2007, 47, 89-116. [CrossRef] [PubMed]

57. Silva-Islas, C.A.; Maldonado, P.D. Canonical and non-canonical mechanisms of Nrf2 activation. Pharmacol. Res. 2018, 134, 92-99. [CrossRef] [PubMed]

58. Rushmore, T.H.; Morton, M.R.; Pickett, C.B. The antioxidant responsive element. Activation by oxidative stress and identification of the DNA consensus sequence required for functional activity. J. Biol. Chem. 1991, $266,11632-11639$.

59. Cheng, X.; Gao, D.; Chen, B.; Mao, X. Endotoxin-binding peptides derived from casein glycomacropeptide inhibit lipopolysaccharide-stimulated inflammatory responses via blockade of NF- $\mathrm{KB}$ activation in macrophages. Nutrients 2015, 7, 3119-3137. [CrossRef] 
60. Li, T.; Cheng, X.; Du, M.; Chen, B.; Mao, X. Upregulation of heme oxygenase-1 mediates the anti-inflammatory activity of casein glycomacropeptide (GMP) hydrolysates in LPS-stimulated macrophages. Food Funct. 2017, 8, 2475-2484. [CrossRef]

61. Sharma, R.S.; Harrison, D.J.; Kisielewski, D.; Cassidy, D.M.; McNeilly, A.D.; Gallagher, J.R.; Walsh, S.V.; Honda, T.; McCrimmon, R.J.; Dinkova-Kostova, A.T.; et al. Experimental Nonalcoholic Steatohepatitis and Liver Fibrosis Are Ameliorated by Pharmacologic Activation of Nrf2 (NF-E2 p45-Related Factor 2). Cell. Mol. Gastroenterol. Hepatol. 2018, 5, 367-398. [CrossRef]

62. Shin, S.; Wakabayashi, J.; Yates, M.S.; Wakabayashi, N.; Dolan, P.M.; Aja, S.; Liby, K.T.; Sporn, M.B.; Yamamoto, M.; Kensler, T.W. Role of Nrf2 in prevention of high-fat diet-induced obesity by synthetic triterpenoid CDDO-imidazolide. Eur. J. Pharmacol. 2009, 620, 138-144. [CrossRef]

63. Hennig, P.; Garstkiewicz, M.; Grossi, S.; Di Filippo, M.; French, L.E.; Beer, H.-D. The crosstalk between Nrf2 and inflammasomes. Int. J. Mol. Sci. 2018, 19, 562. [CrossRef]

64. Thimmulappa, R.K.; Fuchs, R.J.; Malhotra, D.; Scollick, C.; Traore, K.; Bream, J.H.; Trush, M.A.; Liby, K.T.; Sporn, M.B.; Kensler, T.W.J.A.; et al. Preclinical evaluation of targeting the Nrf2 pathway by triterpenoids (CDDO-Im and CDDO-Me) for protection from LPS-induced inflammatory response and reactive oxygen species in human peripheral blood mononuclear cells and neutrophils. Antioxid. Redox Signal. 2007, 9, 1963-1970. [CrossRef]

65. Khor, T.O.; Huang, M.-T.; Kwon, K.H.; Chan, J.Y.; Reddy, B.S.; Kong, A.-N. Nrf2-deficient mice have an increased susceptibility to dextran sulfate sodium-induced colitis. Cancer Res. 2006, 66, 11580-11584. [CrossRef]

66. Khor, T.O.; Huang, M.-T.; Prawan, A.; Liu, Y.; Hao, X.; Yu, S.; Cheung, W.K.L.; Chan, J.Y.; Reddy, B.S.; Yang, C.S. Increased susceptibility of Nrf2 knockout mice to colitis-associated colorectal cancer. Cancer Prev. Res. 2008, 1, 187-191. [CrossRef]

67. Blaser, H.; Dostert, C.; Mak, T.W.; Brenner, D. TNF and ROS crosstalk in inflammation. Trends Cell Biol. 2016, 26, 249-261. [CrossRef]

68. Morgan, M.J.; Liu, Z.-G. Crosstalk of reactive oxygen species and NF-kB signaling. Cell Res. 2011, 21, $103-115$. [CrossRef]

69. Liu, G.-H.; Qu, J.; Shen, X. NF-kB/p65 antagonizes Nrf2-ARE pathway by depriving CBP from Nrf2 and facilitating recruitment of HDAC3 to MafK. Biochim. Biophys. Acta Mol. Cell Res. 2008, 1783, 713-727. [CrossRef]

70. Wardyn, J.D.; Ponsford, A.H.; Sanderson, C.M. Dissecting molecular cross-talk between Nrf2 and NF- $\mathrm{kB}$ response pathways. Biochem. Soc. Trans. 2015, 43, 621-626. [CrossRef]

71. Yu, M.; Li, H.; Liu, Q.; Liu, F.; Tang, L.; Li, C.; Yuan, Y.; Zhan, Y.; Xu, W.; Li, W.J.C.S. Nuclear factor p65 interacts with Keap1 to repress the Nrf2-ARE pathway. Cell. Signal. 2011, 23, 883-892. [CrossRef]

72. Li, G.; Barrett, E.J.; Barrett, M.O.; Cao, W.; Liu, Z.J.E. Tumor necrosis factor- $\alpha$ induces insulin resistance in endothelial cells via a p38 mitogen-activated protein kinase-dependent pathway. Endocrinology 2007, 148, 3356-3363. [CrossRef]

73. Fujishiro, M.; Gotoh, Y.; Katagiri, H.; Sakoda, H.; Ogihara, T.; Anai, M.; Onishi, Y.; Ono, H.; Abe, M.; Shojima, N.J.M.E. Three mitogen-activated protein kinases inhibit insulin signaling by different mechanisms in 3T3-L1 adipocytes. Mol. Endocrinol. 2003, 17, 487-497. [CrossRef]

74. Samuel, V.T.; Shulman, G.I.J.C. Mechanisms for insulin resistance: Common threads and missing links. Cell 2012, 148, 852-871. [CrossRef]

75. Kassi, E.; Pervanidou, P.; Kaltsas, G.; Chrousos, G.J.B.m. Metabolic syndrome: Definitions and controversies. BMC Med. 2011, 9, 48. [CrossRef]

76. Cuadrado, A.; Nebreda, A.R.J.B.J. Mechanisms and functions of p38 MAPK signalling. Biochem. J. 2010, 429, 403-417. [CrossRef]

77. Hotamisligil, G.S.; Davis, R.J.J.C.S.H.p.i.b. Cell signaling and stress responses. Cold Spring Harb. Perspect. Biol. 2016, 8, a006072. [CrossRef]

78. Mackenzie, R.W.; Elliott, B.T.J.D. Akt/PKB activation and insulin signaling: A novel insulin signaling pathway in the treatment of type 2 diabetes. Diabetes Metab. Syndr. Obes. Targets Ther. 2014, 7, 55. [CrossRef]

79. White, M.F. IRS proteins and the common path to diabetes. Am. J. Physiol. Endocrinol. Metab. 2002, 283, E413-E422. [CrossRef] 
80. Wang, Y.; Wei, R.-B.; Yang, Y.; Su, T.-Y.; Huang, M.-J.; Li, P.; Chen, X.-M. Valsartan alleviates insulin resistance in skeletal muscle of chronic renal failure rats. Med. Sci. Monit. Int. Med. J. Exp. Clin. Res. 2018, 24, 2413. [CrossRef]

81. Qin, S.; Chock, P.B.J.B. Implication of phosphatidylinositol 3-kinase membrane recruitment in hydrogen peroxide-induced activation of PI3K and Akt. Biochemistry 2003, 42, 2995-3003. [CrossRef] [PubMed]

82. Sonoda, Y.; Watanabe, S.; Matsumoto, Y.; Aizu-Yokota, E.; Kasahara, T.J.J.o.B.C. FAK is the upstream signal protein of the phosphatidylinositol 3-kinase-Akt survival pathway in hydrogen peroxide-induced apoptosis of a human glioblastoma cell line. J. Biol. Chem. 1999, 274, 10566-10570. [CrossRef] [PubMed]

83. Wang, X.; McCullough, K.D.; Franke, T.F.; Holbrook, N.J. Epidermal growth factor receptor-dependent Akt activation by oxidative stress enhances cell survival. J. Biol. Chem. 2000, 275, 14624-14631. [CrossRef]

84. Manning, B.D.; Toker, A.J.C. AKT/PKB signaling: Navigating the network. Cell 2017, 169, 381-405. [CrossRef]

85. Martindale, J.L.; Holbrook, N.J. Cellular response to oxidative stress: Signaling for suicide and survival. J. Cell. Physiol. 2002, 192, 1-15. [CrossRef]

86. Ilboudo, S.; Fouche, E.; Rizzati, V.; Toé, A.M.; Gamet-Payrastre, L.; Guissou, P.I. In Vitro impact of five pesticides alone or in combination on human intestinal cell line Caco-2. Toxicol. Rep. 2014, 1, 474-489. [CrossRef]

87. Wang, X.; Chen, W.R.; Xing, D. A pathway from JNK through decreased ERK and Akt activities for FOXO3a nuclear translocation in response to UV irradiation. J. Cell. Physiol. 2012, 227, 1168-1178. [CrossRef]

88. Meier, R.; Thelen, M.; Hemmings, B.A. Inactivation and dephosphorylation of protein kinase $\mathrm{B} \alpha(\mathrm{PKB} \alpha)$ promoted by hyperosmotic stress. EMBO J. 1998, 17, 7294-7303. [CrossRef]

89. Konishi, H.; Matsuzaki, H.; Tanaka, M.; Takemura, Y.; Kuroda, S.I.; Ono, Y.; Kikkawa, U. Activation of protein kinase B (Akt/RAC-protein kinase) by cellular stress and its association with heat shock protein Hsp27. FEBS Lett. 1997, 410, 493-498. [CrossRef]

90. Klotz, L.-O.; Schieke, S.M.; Sies, H.; Holbrook, N.J. Peroxynitrite activates the phosphoinositide 3-kinase/Akt pathway in human skin primary fibroblasts. Biochem. J. 2000, 352, 219-225. [CrossRef]

91. Huang, C.; Li, J.; Ding, M.; Leonard, S.S.; Wang, L.; Castranova, V.; Vallyathan, V.; Shi, X. UV Induces phosphorylation of protein kinase B (Akt) at Ser-473 and Thr-308 in mouse epidermal Cl 41 cells through hydrogen peroxide. J. Biol. Chem. 2001, 276, 40234-40240. [CrossRef]

92. Zhou, Y.; Wang, Q.; Evers, B.M.; Chung, D.H. Signal transduction pathways involved in oxidative stress-induced intestinal epithelial cell apoptosis. Pediatric Res. 2005, 58, 1192. [CrossRef]

93. Moniruzzaman, M.; Ghosal, I.; Das, D.; Chakraborty, S.B. Melatonin ameliorates $\mathrm{H}_{2} \mathrm{O}_{2}$-induced oxidative stress through modulation of Erk/Akt/NFkB pathway. Biol. Res. 2018, 51, 17. [CrossRef]

94. Kennedy, S.G.; Kandel, E.S.; Cross, T.K.; Hay, N.J.M. Akt/Protein kinase B inhibits cell death by preventing the release of cytochrome $\mathrm{c}$ from mitochondria. Mol. Cell. Biol. 1999, 19, 5800-5810. [CrossRef]

95. Zhang, X.-S.; Wang, T.; Lin, X.-W.; Denlinger, D.L.; Xu, W.-H. Reactive oxygen species extend insect life span using components of the insulin-signaling pathway. Proc. Natl. Acad. Sci. USA 2017, 114, E7832-E7840. [CrossRef]

96. Li, T.; Gao, D.; Du, M.; Cheng, X.; Mao, X. Casein glycomacropeptide hydrolysates inhibit PGE2 production and COX2 expression in LPS-stimulated RAW 264.7 macrophage cells via Akt mediated NF-kappaB and MAPK pathways. Food Funct. 2018, 9, 2524-2532. [CrossRef]

97. Ozes, O.N.; Mayo, L.D.; Gustin, J.A.; Pfeffer, S.R.; Pfeffer, L.M.; Donner, D.B.J.N. NF-kB activation by tumour necrosis factor requires the Akt serine-threonine kinase. Nature 1999, 401, 82-85. [CrossRef]

98. Oeckinghaus, A.; Hayden, M.S.; Ghosh, S. Crosstalk in NF-kB signaling pathways. Nat. Immunol. 2011, 12, 695. [CrossRef]

99. Bautista, E.; Vergara, P.; Segovia, J.J. Iron-induced oxidative stress activates AKT and ERK1/2 and decreases Dyrk1B and PRMT1 in neuroblastoma SH-SY5Y cells. J. Trace Elem. Med. Biol. 2016, 34, 62-69. [CrossRef]

100. Uranga, R.M.; Mateos, M.V.; Giusto, N.M.; Salvador, G.A. Activation of phosphoinositide-3 kinase/Akt pathway by $\mathrm{FeSO}_{4}$ in rat cerebral cortex synaptic endings. J. Neurosci. Res. 2007, 85, 2924-2932. [CrossRef]

101. Uranga, R.M.; Giusto, N.M.; Salvador, G.A. Iron-induced oxidative injury differentially regulates PI3K/Akt/GSK3 $\beta$ pathway in synaptic endings from adult and aged rats. Toxicol. Sci. 2009, 111, 331-344. [CrossRef] [PubMed] 
102. Chen, L.; Xiong, S.; She, H.; Lin, S.W.; Wang, J.; Tsukamoto, H. Iron causes interactions of TAK1, p21ras, and phosphatidylinositol 3-kinase in caveolae to activate IkB kinase in hepatic macrophages. J. Biol. Chem. 2007, 282, 5582-5588. [CrossRef] [PubMed]

103. Uranga, R.M.; Katz, S.; Salvador, G.A. Enhanced phosphatidylinositol 3-kinase (PI3K)/Akt signaling has pleiotropic targets in hippocampal neurons exposed to iron-induced oxidative stress. J. Biol. Chem. 2013, 288, 19773-19784. [CrossRef] [PubMed]

104. Ndong, M.; Kazami, M.; Suzuki, T.; Uehara, M.; Katsumata, S.-I.; Inoue, H.; Kobayashi, K.-I.; Tadokoro, T.; Suzuki, K.; Yamamoto, Y. Iron deficiency down-regulates the Akt/TSC1-TSC2/mammalian Target of Rapamycin signaling pathway in rats and in COS-1 cells. Nutr. Res. 2009, 29, 640-647. [CrossRef] [PubMed]

105. Watson, A.; Lipina, C.; McArdle, H.J.; Taylor, P.M.; Hundal, H.S. Iron depletion suppresses mTORC1-directed signalling in intestinal Caco-2 cells via induction of REDD1. Cell. Signal. 2016, 28, 412-424. [CrossRef]

106. Gamble, J.; Lopaschuk, G.D. Insulin inhibition of 5' adenosine monophosphate-Activated protein kinase in the heart results in activation of acetyl coenzyme A carboxylase and inhibition of fatty acid oxidation. Metabolism 1997, 46, 1270-1274. [CrossRef]

107. Witters, L.; Kemp, B.E. Insulin activation of acetyl-CoA carboxylase accompanied by inhibition of the 5'-AMP-activated protein kinase. J. Biol. Chem. 1992, 267, 2864-2867.

108. Da Silva Xavier, G.; Leclerc, I.; Salt, I.P.; Doiron, B.; Hardie, D.G.; Kahn, A.; Rutter, G.A. Role of AMP-activated protein kinase in the regulation by glucose of islet beta cell gene expression. Proc. Natl. Acad. Sci. USA 2000, 97, 4023-4028. [CrossRef]

109. Hahn-Windgassen, A.; Nogueira, V.; Chen, C.-C.; Skeen, J.E.; Sonenberg, N.; Hay, N. Akt activates the mammalian target of rapamycin by regulating cellular ATP level and AMPK activity. J. Biol. Chem. 2005, 280, 32081-32089. [CrossRef]

110. Kovacic, S.; Soltys, C.-L.M.; Barr, A.J.; Shiojima, I.; Walsh, K.; Dyck, J.R. Akt activity negatively regulates phosphorylation of AMP-activated protein kinase in the heart. J. Biol. Chem. 2003, 278, 39422-39427. [CrossRef]

111. Horman, S.; Vertommen, D.; Heath, R.; Neumann, D.; Mouton, V.; Woods, A.; Schlattner, U.; Wallimann, T.; Carling, D.; Hue, L. Insulin antagonizes ischemia-induced Thr172 phosphorylation of AMP-activated protein kinase $\alpha$-subunits in heart via hierarchical phosphorylation of Ser485/491. J. Biol. Chem. 2006, 281, 5335-5340. [CrossRef] [PubMed]

112. Jeon, S.-M. Regulation and function of AMPK in physiology and diseases. Exp. Mol. Med. 2016, 48, e245. [CrossRef] [PubMed]

113. Towler, M.C.; Hardie, D.G. AMP-activated protein kinase in metabolic control and insulin signaling. Circ. Res. 2007, 100, 328-341. [CrossRef] [PubMed]

(C) 2020 by the authors. Licensee MDPI, Basel, Switzerland. This article is an open access article distributed under the terms and conditions of the Creative Commons Attribution (CC BY) license (http://creativecommons.org/licenses/by/4.0/). 